\title{
CAROTID ARTERY DISEASE IN DIABETIC PATIENTS
}

\section{Marijan Bosevski}

University Cardiology Clinic, Medical Faculty, Skopje, R. Macedonia

Corresponding Author: University Cardiology Clinic, Medical Faculty, University Ss. Cyril and Methodius, 1000 Skopje, R. Macedonia, Tel: +389 (0)2 31479 18, E-mail: marijanbosevski@yahoo.com

\begin{abstract}
There are two points of view on the interplay between carotid artery disease and diabetes mellitus: Diabetes mellitus has been recognized as one of the main determinants for the presence and progression of asymptomatic and symptomatic carotid artery disease; and carotid intima-media thickness has been defined as a useful tool for risk stratification of this population.

Hyperglycaemia, duration of diabetes, arterial hypertension, cholesterol and inflammatory markers have previously been determined as independent factors for carotid atherosclerosis in diabetes, and aging as its predictor in this population by our own results. This paper focuses on the particularities of risk factors in diabetic patients (especially in type 2) and evidence-based guidelines for the management and risk reduction of these patients with stroke and/or carotid artery disease.

At present, carotid ultrasound is recommended in diabetic patients with cerebrovascular symptoms. Since the prevalence of diabetes increases constantly, we attempt to address refreshment of criteria for screening of carotid artery disease in the diabetic population. It could be recommended for diabetic patients with at least one more risk factors and for diabetic patients above 60 years of age.
\end{abstract}

Key words: carotid artery disease, diabetes, stroke, carotid ultrasound, aging, prognosis.

\section{Introduction}

Diabetic vascular disease is the main reason for morbidity and mortality in diabetic patients (pts).

Two thirds of all cause of deaths in Diabetes mellitus (DM) belong to macrovascular disease, and $25 \%$ of them belong to cerebrovascular disease. $60 \%$ of the expenses for treatment of type 2 diabetes are aimed at treatment of vascular disease, and $9 \%$ of them at cerebrovascular disease $[1,1 \mathrm{~b}]$.

\section{Carotid artery disease and Stroke in Type 2 diabetes}

\section{Stroke and Diabetes}

Diabetes Mellitus (DM) has been recognized as one of the most important factors for the development of cerebrovascular disease, defined as ischaemic stroke or asymptomatic carotid stenosis (Cincinnati/North Kentucky Study) [2, 2b]. Risk of ischaemic stroke in diabetic patients is higher in every age- and racegroup compared to nondiabetic groups. A three to 10 -fold risk of stroke-reffered diabetic pts is included in MRFIT and Baltimore-Washington Cooperative Stroke Studies. A multivariate analysis with regards to ischaemic stroke found population attributable risk of diabetes in a range of $5 \pm 22 \%$ (Northern Manhattan Stroke and Rochester Studies). According ARIC follow-up diabetic pts without coronary artery diease reffered have a similar relative risk of stroke as nondiabetic pts with coronary artery disease. There is a relative risk of stroke in diabetic pts from 2.1 to $5.8[3,3 b]$. 
There is a strong relation between type 2 diabetes and the occurrence and recurrence of stroke, according Tokyo Metropolitan Hospital Series and South London Stroke Register [45]. Kuusisto's study revealed type 2 diabetes as an important predictor of stroke onset in elderly people [6].

Tuomelhto's study group referred to the fact that in a population with stroke only $20 \%$ have normal glycaemia [7] There is a prevalence of Diabetes Mellitus in a stroke population in a range of 15 to $20 \%$ [8].

Patients with ischaemic stroke and diabetes have had more frequent arterial hypertension, previous coronary artery disease and hypercholesterolaemia vs. those without diabetes. There are differences in the clinical presentation of stroke in diabetic pts. These pts referred had a higher prevalence of lacunar infarcts and lower neurological deficits at entrance [9, 10]. Lacunar syndrome in diabetics is often accompanied by asymptomatic cerebral ischaemia and arterial hypertension.

As the result of a high prevalence of atrial fibrillation and heart failure, cardiac thrombembolism could be found in pts with DM [11, 12]. Framingham Heart and Manitoba Followup Studies revealed diabetes with a relative risk of 1.4 to 1.8 for the occurrence of atrial fibrillation $[13,14]$. Atherosclerotic aorta-origin could also be a source of brain embolism. Lammie described degenerative abnormalities, such as lipohyalinosis and fibrinoid changes, as causes of subcortical brain infarcts in diabetics [15].

\section{Carotid artery disease in Type 2 diabetes}

Extracranial and intracranial carotid artery disease and diabetic microvascular disease are the main determinants of stroke in diabetics [16]. Diabetes is associated with large- and small-artery brain atherosclerosis, causing a change of flow.

Anatomical studies found carotid artery disease in diabetics with unstable and vulnerable plaques, which could provoke thromboembolism additionally [17].

Patients with Diabetes mellitus referred with a higher value of carotid intima-media thickness (CIMT) vs. non diabetics. Glycaemic control measured as fasting glycaemia or $\mathrm{Hba1C}$ has been found as independent factors for CIMT value in diabetics (RIAD) [18-19]. In the AIR-population-based study on atherosclerosis and insulin resistance, increased CIMT and plaque size were found in advanced stages of impaired (lost) glucose control. In the DIWA study CIMT was greates in women with known type 2 diabetes vs. those with normal glucose tolerance [19b]. This study did not observe an association between impaired glucose tolerance and increased CIMT or carotid plaque occurrence.

Carotid IMT is related to diabetes duration and plasma cholesterol in patients with type 2 diabetes, and with postprandial glycaemia in the general population (IRAS). IRAS and $A R I C$ studies referred to a mean value of CIMT of 0.91 and $0.89 \mathrm{~mm}$ in a population with type 2 diabetes [20-21]. That is comparable with results from our data of 340 patients with type 2 diabetes, presenting a mean CIMT $0.89 \pm$ $1.59 \mathrm{~mm}$ and max CIMT of $0.99 \pm 1.95 \mathrm{~mm}$.

Diabetes mellitus is an independent factor for high grade carotid stenosis in the general population [22]. Type 2 diabetes is a factor that determinates the progression of carotid atherosclerosis, measured as a progression of CIMT and the occurrence of plaque in the internal carotid artery [23-24].

The pathogenesis of carotid artery disease in a type 2 diabetes population is based on a cluster of metabolic factors such as: insulin resistance, hyperlipidaemia, obesity and arterial hypertension [27-28]. Independent factors for carotid artery disease in diabetics are arterial hypertension, hypercholesterolaemia and inflammatory markers CRP and fibrinogen [25-26].

Non HDL-cholesterol is found as an independent predictor for ischaemic stroke and total cardiovascular risk in the type 2 diabetic population [29, 30]. Non HDL-cholesterol correlates with CIMT value in type 2 diabêtes [31]. The IRAS study revealed a positive relation of carotid atherosclerosis with LDL-cholesterol, and an inverse relation with HDLcholesterol. Metabolic syndrome amplifies LDLcholesterol associated increasing for carotid atherosclerosis in the general population [32]. LDL-cholesterol independently influences increasing CIMT and the occurrence of carotid plaques in population-based studies where diabetic patients are included [34]. High blood 
pressure and abdominal obesity are factors influencing the CIMT [35-36]. Pts with diabetic nephropathy revealed greater CIMT than those without. Renal involvement accelerates carotid atherosclerosis in a population with type 2 diabetes [37-38]. Bilateral carotid stenosis is probably a determinate from a complex mechanism based on the atherothrombotic process and involvment of many risk factors.

\section{Prognostic implications}

Diabetes has been defined as a stronger risk factor for stroke-related mortality than arterial hypertension or hyperlipidaemia. Diabetes mellitus causes $16 \%$ of stroke mortality in men and 30\% in women [39].

Prognosis of pts with a stroke and Diabetes mellitus is dependent on glycaemia and glycated haemoglobin [40 $\$ 42]$. Hyperglycaemia that was found in an acute phase of stroke is recognized as important factor for cerebral damage through oxidative and inflammatory mechanisms [43]. Strong evidence between glycaemia and risk of cerebrovascular events in diabetics has not been found. On the other hand $\mathrm{HbA} 1 \mathrm{C}$, as a parameter of glycometabolic control, is an independent factor for future cerebrovascular events [45]. Duration of diabetes is also an important predictor of stroke in type 2 diabetes (Copenhagen Stroke Study, Finnish Study) [44, 46]. In many studies surviving stroke pts with diabetes have been shown to have a worse outcome. According to the Cincinnati/North Kentucky Study diabetic pts are more likely to survive with disability after an ischaemic stroke. No published data has gound a unique profile for ischaemic stroke in diabetics. Studies by Lithner and Toni reported that stroke severity was similar in diabetics and nondiabetics [47-48]. But Kiers and Pulsinelli reported a poorer outcome of stroke in diabetic pts [49-50].

Furthermore, hyperglycaemia and advanced gyration products could damage the brain structure. These are the reasons that population-based studies by Leibson, Ott suggested that diabetes has been associated with vascular dementia. More consistent are the results of the Honolulu Asia-Aging Study, providing evidence of the association between diabetes, genetic base and the occurrence of dementia [51]. Older individuals with type 2 diabetes have an elevated risk of brain vascular damage and neurovegetative changes. Those with longest diabetes duration and treated with insulin referred more brain changes. Pathological brain changes in diabetic pts might be a basis for a higher risk of dementia [52].

Risk stratification schemes in pts with a stroke considered age, previous history of stroke, TIA, coronary artery disease or heart failure, and traditional risk factors such as diabetes or arterial hypertension. According to the AFI scheme diabetic pts are considered as high risk pts, independent of their age. The American College of Chest Physicians classified diabetic pts as a medium risk population. They are at high risk if another risk factor is present [53]. The Joint Task Force of American Heart Association (AHA)/American College of Cardiology (ACC)/European Society of Cardiology (ESC) classified diabetic and age > 75 years as moderate risk factors together with arterial hypertension, heart failure and left ventricular ejection fraction $<35 \%$ [54]. Diabetes and age are determinants of Framingham and CHADS prediction scores for stroke. The latter considered age $>75$ years as an independent risk factor for the prediction of future stroke [55, 56].

\section{Treatment of carotid artery disease and/or stroke in diabetic patients}

Diabetic pts with cerebrovascular disease should be treated for risk factors: arterial hypertension and hyperlipidaemia (Table 1).

Arterial hypertension is independently associated with the rate of mortality and myocardial infarction and future stroke in type 2 diabetes [57-58]. Regulation of blood pressure in diabetics is more useful than in nondiabetics regarding total cardiovascular risk [59].

Recent studies have reported that aggressive blood pressure reduction significantly reduced stroke. Therefore, a tighter control of blood pressure is required to prevent stroke in diabetic patients as compared with non-diabetic subjects. The desirable target pressure is less than $130 / 80 \mathrm{mmHg}$.

Angiotensin Converting Enzyme (ACE) inhibitors have been found useful to be administered to these pts, according to the HOPE and PROGRESS study [60]. LIFE study found the same trend when angiotensin receptor bloc- 
kers (ARB) were used [61]. Cochrane, a collaboration librarian who conducted an independent MEDLINE search from 2006 to 2007, recommended an ACE inhibitor/diuretic combi- nation in patients with cerebrovascular disease, and an ACE inhibitor and ARB in patients with diabetes mellitus [62].

Table 1

Recommendation for diabetic pts, aimed at primary and secondary prevention of stroke

\begin{tabular}{||c|c||}
\hline CLASS OF & RECOMMENDATION \\
RECOMMENDATION & Treatment of arterial hypertension \\
\hline I & ACE inhibitors administration \\
\hline IIa & Statins \\
\hline I & Acetyl salicilc acid \\
\hline I & Clopidogrel in certain cases \\
\hline IIb & Glycometabolic control \\
\hline IIa &
\end{tabular}

Treatment in older patients should be almost the same as in younger patients, although blood reduction should be attempted safely and step by step. The use of $\mathrm{Ca}$ antagonists is recommended as first-line drugs by Kawamura, as ACE inhibitor, for achieving it [63].

Antithrombotic therapy is indicated for the prevention of stroke in diabetics. The first choice is Acetyl Salicilic Acid (ASA) in a low dose [61]. Clopidogrel reduces the future relative risk in these pts [62]. Clopidogrel is administered in case of Aspirin intolerance or in combination with ASA in pts with recurrent stroke. Dual antithrombotic therapy has been recognized as less safe regarding bleeding if it is administered for a long-term period (MATCH, CHARISMA trials) [63-65]. In the CAPRIE study on patients with multiple vascular bed involvement, the annual events rate in patients who received ASA was $19.84 \%$, compared with a rate of $17.39 \%$ in individuals receiving clopidogrel. This group, including those with carotid artery disease, also derived greater benefit from Clopidogrel treatment than did low-risk patients. The CAPRIE trial included 3,866 patients with diabetes. The events rate was higher in this group than in the population as a whole. As with other high-risk populations, patients with diabetes derived a greater benefit from clopidogrel than from ASA therapy. Clopidogrel prevented 21 more events per 1000 diabetic patients treated than did ASA. The events rate in patients with diabetes receiving insulin was higher than in diabetic patients as a whole, and these patients also achieved an even greater benefit with clopidogrel treatment than did diabetic patients as a whole. In insulintreated diabetic patients, the rate was $21.5 \%$ for those receiving ASA and $17.7 \%$ for those receiving clopidogrel - a relative risk of $16.7 \%$. Clopidogrel prevented 38 more events per 1000 diabetic patients receiving insulin than did ASA.

AHA/ACC/ESC Guidelines recommendded oral anticoagulant therapy for pts with permanent or paroxysmal atrial fibrillation and a history of stroke or TIA. Pts with more than one moderate risk factor for thrombo-embolism (Diabetes mellitus included) should also be treated with an anticoagulant drug. Chronic oral anticoagulant therapy should be administered to diabetic patients with atrial fibrillation and the presence of a risk factor for thrombembolism (class IIA). Aspirin and anticoagulants are recommended for diabetic pts with atrial fibrillation to prevent stroke (class I). The target value of INR should be from 2 to 3 , independently of age or other risk factors. A lower INR target (1.6-2) may be considered in pts with a high risk of bleeding [61].

The negative influence of glycaemia in nondiabetic pts presenting with a stroke is also well documented, as it was in diabetics. It is important to detect diabetes early and to regulate glycaemia in pts with a stroke [67]. But there is not sufficient data from controlled stu- 
dies that glycaemic control will be beneficial for newly diagnosed diabetic pts with a stroke.

Appropriate antidiabetic treatment will improve the prognosis of diabetic pts with a stroke (UKPDS). Group intensive blood-glucose control with sulfonylurea or insulin compared with conventional treatment and risk of complications in pts with type 2 diabetes (UKPDS 33). There is evidence-based data that lifestyle modification could reduce the progression of impaired glucose tolerance to diabetes, as much as risk factors for stroke: arterial hypertension, obesity and dyslipidaemia. It is important and could be achieved for better a prognosis for stroke pts [69].

Statins achieve a significant reduction in total and LDL-cholesterol and have important plaque-stabilizing properties. The Heart Protection Study referred to a stroke reduction in the diabetic population when Simvastatin was used [70]. There is evidence-based data regarding stroke reduction using statins. Acute stroke in diabetic pts should be treated on the same principles as the general population. Thrombolysis is effective if administered in the first four hours. Optimization of circulation and glycometabolic control are part of conservative treatment. In the acute phase the value of blood pressure should be reduce up to $25 \%$ from its initial value [61].

The aim of carotid revascularization is to prevent a stroke by removing an obstruction of blood flow to the brain and preventing arteryto-artery thrombembolism [70b]. There are no differences in guidelines for carotid revascularization between the diabetic and non-diabetic population. There is a high probability of carotid restenosis after endarterectomy and future vascular events in patients with DM, as referred to in studies: USFS, ELOCAS, SAPHIRE [71-72]. Diabetics referred a higher rate of mortality and intracerebral haemorrhage, but not myocardial infarction, in the perioperative period after carotid endarterectomy [73]. The rate for perioperative stroke and death after carotid endarterectomy in pts older than 75 years is $7.5 \%$. Approved indications for carotid revascularization are: carotid stenosis > 50\% with a history of stroke or TIA. Pts with stroke in development and carotid stenosis > 70\% could benefit from revascularization, but this indication is not approved. Symptomatic ulce- rative carotid artery disease with carotid stenosis $>50 \%$ should be treated according to the mentioned indications. There are diffident indications for revascularization in the presence of: progressive stroke with carotid stenosis $>50 \%$, acute dissection of internal carotid artery, acute carotid occlusion in first 6 hours, and history of TIA with carotid stenosis $<70 \%$ [74].

The Cochrane systematic review including randomized trials: NASCET, ECST, ACAS and ACST supports carotid endarterectomy for symptomatic carotid stenosis $>50 \%$, and asymptomatic carotid stenosis $>60 \%$ [75]. The American Heart Association suggests a 6\% upper limit for perioperative risk in symptomatic pts, and $3 \%$ in asymptomatic pts. Pts with tortuous carotid arteries, presence of calcified plaques, lumen diameter of internal carotid artery smalller than $3 \mathrm{~mm}$ are served with endarterectomy as the first line of carotid revascularization.

Published data regarding carotid stenting (CARESS, SAPPHIRE, CABERNET, ARCHeR, CAPTURE, BEACH, ALKK, CASES-PMS, $C R E A T E$ ) show this revascularization procedure as not inferior to endarterectomy. Studies: CAVATAS, Wallstent, EVA-3S did not imply the use of distal protection devices and demonstrated a significant proportion of neurological complications after carotid stenting (Pictute 1).

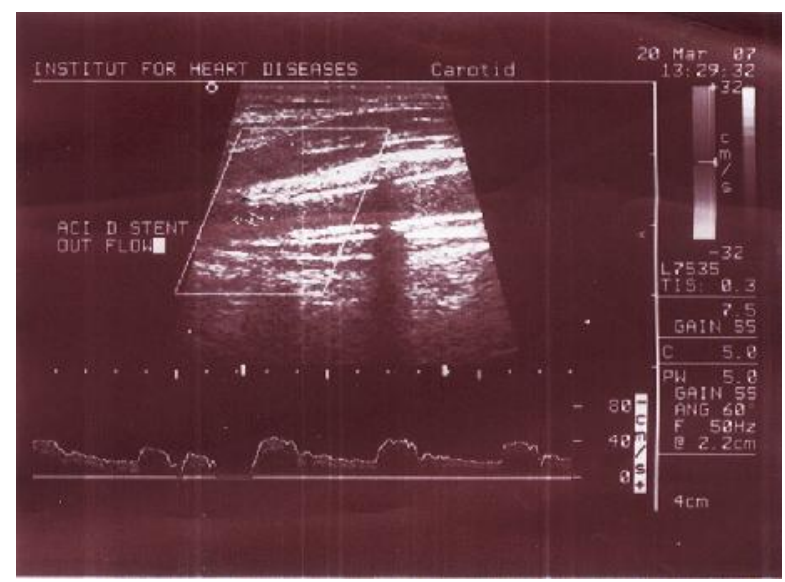

Picture 1 - Ultrasound scan of stent in internal carotid artery and measurement of out flow velocities (own collection)

This procedure is recommended for high risk pts selected with anatomical characteristics and medical comorbidities [76]. Anatomical criteria include: non accessible lesions for surgery, restenosis after endarterctomy, bilateral carotid stenosis, intracranial stenosis or pre- 
vious neck surgery or radiation. Comorbidities such as unstable angina, heart failure, planned by-pass surgery, met the high risk categoryzation. Advanced age $>75$ years is a selection criterion for a high risk patient [74-75]. Ongoing trials (TACIT, CREST) will give more insight into control of pt's specific risk factors (Diabetes mellitus included), vs. optimal medical therapy and carotid endarterectomy /or stenting.

\section{Carotid ultrasound in the diabetic population}

The concept of total cardiovascular risk in diabetic patients is based on the results of Framingham, PROCAM, Multiple Risk Factors Study [77]. When diabetic patients refer with an absolute risk of future coronary/or cerebrovascular events $>20 \%$, or a relative risk $>5 \%$ compared to the general population, it is necssary to implement the European Society for Cardiology's and American Diabetes Association's Guidelines for treatment or secondary prevention. Framingham, UKPDS and FINDRISC scores are user-friendly worldwide [79-80]. These tools do not consider asymptomatic vascular disease in their aim to stratify a risk in diabetic patients.

Prognosis of pts with type 2 diabetes depends on the presence of diabetic vascular disease. Two thirds of deaths result from macrovascular complications, and $25-50 \%$ of them are due to carotid and peripheral arterial disease [81-83]. The London Cohort Study defined glycaemia, HbA1C, peripheral arterial disease and carotid stenosis as predictors for the prognosis of T2D pts [84].

The American Heart Association, in order to estimate the cardiovascular risk in type 2 diabetes, recommends screening for asymptomatic vascular disease and its treatment [85].

The recommendation of screening consists of noninvasive determination of the anklebrachial index and imaging of carotid arteries in order to assess CIMT. Exercise test and Multisliced Computer Tomography (MCT) of vessels have additional prognostic value in this population [86].

Carotid ultrasound is recommended to be used in stroke and carotid bruits [87]. As a result of the low prevalence of carotid artery disease in diabetic pts $(4.5 \%)$, expenses for devices, training and general screening is not wi- dely recommended. The clinical role of carotid screening is controversial, as the Asymtomatic Carotid Atheroscleoriss Study showed a nonsignificant risk reduction in death and stroke risk after endarterectomy of asymptomatic carotid stenosis. The probability of finding carotid artery disease in type 2 diabetic pts is higher when peripheral arterial disease is diagnosed [87b].

There is a positive trend in the increase of diabetes prevalence worldwide. There is increasing evidence that diabetic cardiovascular complications are the most common cause of death and disability in these pts.

Duval et al. suggest refreshment of criteria for indication for carotid examination in diabetics [87].

Carotid ultrasound should be used in every diabetic pt, not only if cerebrovascular symptomatology present, but also in the presence of: coronary artery disease, arterial hypertension, hyperlipidaemia, age $>60$ years, smoking, renal failure, long diabetes duration and uncontrolled diabetes [88].

Results of studies dealing with the prognostic role of carotid ultrasound in diabetic or type 2 diabetic populations indicate widening the indications for carotid screening, also.

IMT, measured at the level of common or internal carotid arteries (CIMT), has a prognostic role in determining global cardiovascular risk in the general population and the population with coronary artery disease [89, 89b]. CIMT represents the cumulative effect of predisposing factors of risks, which is why it could predict future risk [90]. Throughmeasuring CIMT we can follow the effects of therapy in relation to the presented risk factors [91].

CIMT is significantly greater in diabetic pts than in nondiabetic pts. IRAS and ARIC studies referred to a mean CIMT of 0.91 and $0.88 \mathrm{~mm}$ in the diabetic population (Picture 2).

There is a higher rate of CIMT progression in pts with DM on standard therapy, vs. those with intensive therapy. In his systematic review Bots deals with the use of statin and antihypertensive drugs, aiming to attenuate the rate of progression of CIMT and to reflect the cardiovascular risk [92].

The presence of carotid plaques is a superior factor influencing the prognosis of coronary artery disease more than CIMT [94-95]. 
All of these studies included a significant part of the diabetic subpopulation.

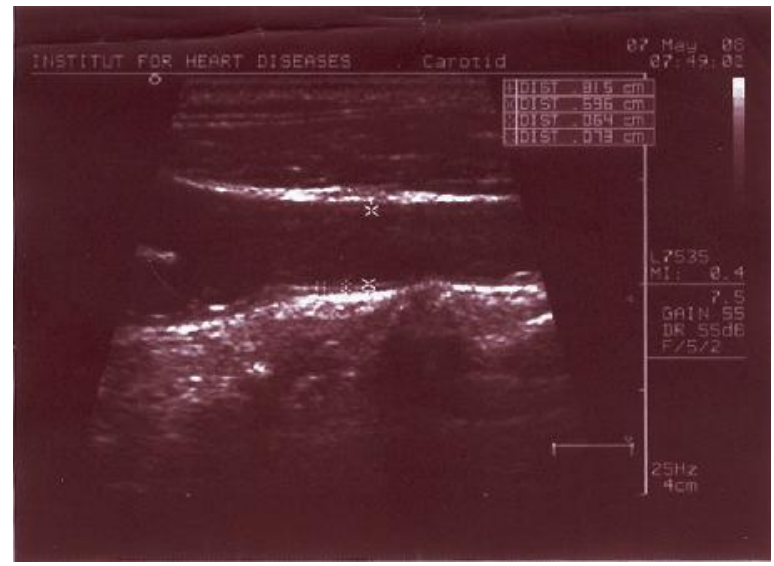

Picture 2 - Ultrasound scan of increased IMT in common carotid artery (own collection)

Lee and Matsumoto referred to a strong relation between increased CIMT and carotid plaques with an ischaemic stroke in type 2 diabetics [96].

Studies: Kuopio Iishemic Heart Disease Risk Factor, Rotterdam, Cardiovascular Health, Malmo Diet Study, ARIC, LILAC, CAPS, and meta-analysis of Lorenz presented carotid plaques and stenosis as superior predictors for future coronary and cerebrovacsular events including mortality (Picture 3) [98-99].

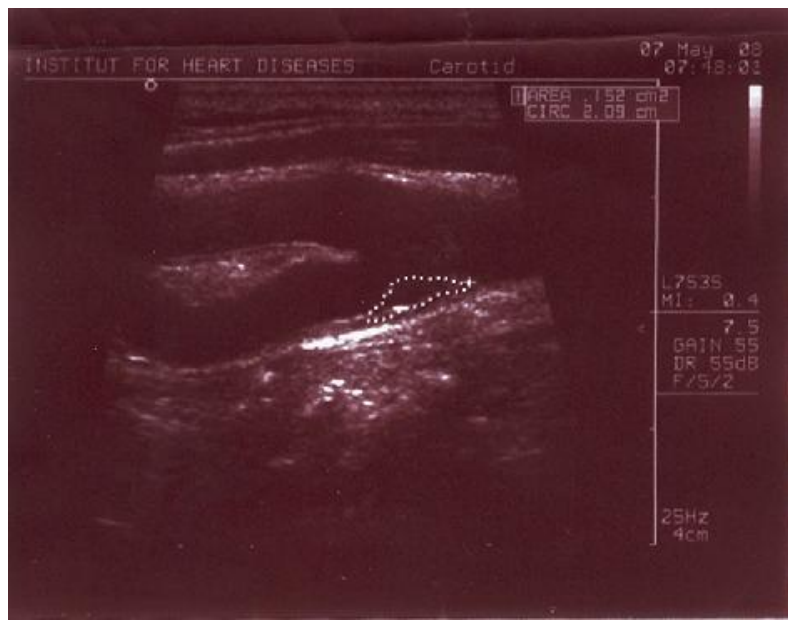

Picture 3 - Ultrasound scan of echolucent plaque on carotid bulb

The prevalence of carotid artery disease in the DM population, defined as presence of plaque, is over $50 \%$ [99b]. Advanced carotid atherosclerosis is related to glycaemia, and lipid profile, as well to over all cardiovascular risk in these pts [100-101]. Ultrasound measu- rements of progression of carotid IMT, carotid plaque area and volume (three dimensional acquisitions for the last ones), are correlated with type 2 diabetes and vascular events. Use of this method is of clinical usefulness and has a future perspective [103-104]. Ragi recommended CIMT and MCT for coronary calcium to estimate the risk in diabetic pts without presence of vascular disease. CIMT value $>1 \mathrm{~mm}$, and or calcium score $>400$ put these pts at high risk, where medical therapy is necessary [105].

Carotid artery disease is related to the presence of coronary artery disease in the type 2 diabetic population [106] the incremental value of carotid ultrasound in prognosis of pts with type 2 diabetes who are asymptomatic for coronary artery disease is presented by a few studies in the last two years [107-109]. The systematic reviw by Brohall presented CIMT with a prognostic value for future cardiovascular events [110]. There is a two- to four-fold relative risk of future events regarding $0,1 \mathrm{~mm}$ CIMT.

Measurements of CIMT may provide good prognostic information during atherosclerosis screening programmes in the type 2 diabetic population. Our unpublshed data presented maximal CIMT as a predictor for cardiovascular mortality (Fig. 1) and carotid stenosis for cardiovascular events with two-fold risk (OR 2,246 95\% CI 0,487-10,359. Our results have made a contribution in this way.

\section{Normal P-P Plot of DEL.IM.M}

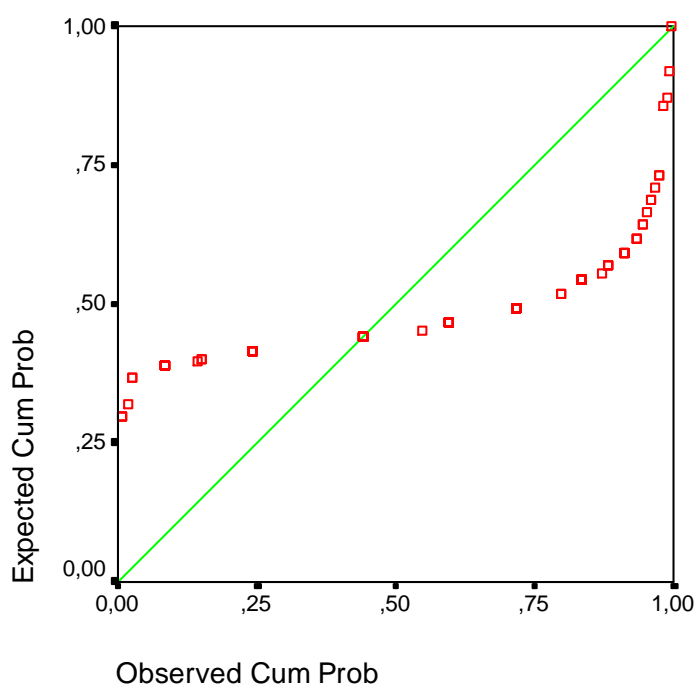

Figure 1 - Regression probability of occurrence of cardiovascular death in type 2 diabetes depends on maximal value of CIMT 
$A R I C, I R A S, C H T$ studies referred to progression of CIMT of 0.05-0.07 mm annually. Studies dealing with type 2 diabetic population rfeefred for progression of CIMT of $0,1 \mathrm{~mm}$ annualy.

Hodis presented that a change in CIMT of $0.03 \mathrm{~mm}$ annually is associated with a relative risk of 2.2 for future coronary events. This meta-analysis was done on high risk patients [111]. According to Lorenz's meta-analysis every change of CIMT by 0.1 increases the relative risk of coronary or cerebrovasclar events by 10 to $30 \%$ [99]. CIMT progression, a priori, is determined from the same risk factors as coronary artery disease. It is not surprising that it can determine a predictive role in coronary events [112]. Aging could additionally influence the progression of carotid atherosclerosis (EVA, CAPS) [113-116].

\section{Influence of Aging and Diabetes On Carotid Artery Disease}

The risk of stroke increases with age. The annual risk increases from $1.5 \%$ in subjects aged $50-50$ years to $23.5 \%$ for those aged 80 89 [117]. This was confirmed by multivariate analysis, made by the AF Investigators Group, which revealed increasing age, diabetes, and arterial hypertension and previous stroke as factors for stroke onset [118].

The subgroup of old people in the type 2 diabetic population presented a high risk of ischaemic stroke [119]. Age, according to the $D A I$ study, has been presented as an independent predictor of ischaemic stroke in type 2 diabetes [120].

The results of the Hoorn study showed that DM accelerated the aging of arterial vessels [116]. DM is associated with an increasing prevalence of $\mathrm{CAD}$, equivalent to the aging of vessels by 20 years, or 10 years in men.

The occurrence of carotid plaques depends on the aging of pts. The Malmo study defined age as an independent factor for increased CIMT in the general population [117]. CIMT depends on diabetes duration. The hazard ratio and CIMT value are multiplicities in older pts with long diabetes duration.

Unpublished data from our Vascular Centre' study included 340 pts with type 2 diabetes. Results revealed a correlation between ma- ximal value of CIMT and age in type 2 diabetics by Pearson analysis $(\mathrm{r}=0.498, \mathrm{p}=0.03$ ) (Figure 2). After the multivariate linear regression model was built, aging by 1 year has influenced an increase in CIMT by $13.6 \%$ to $15.4 \%$.

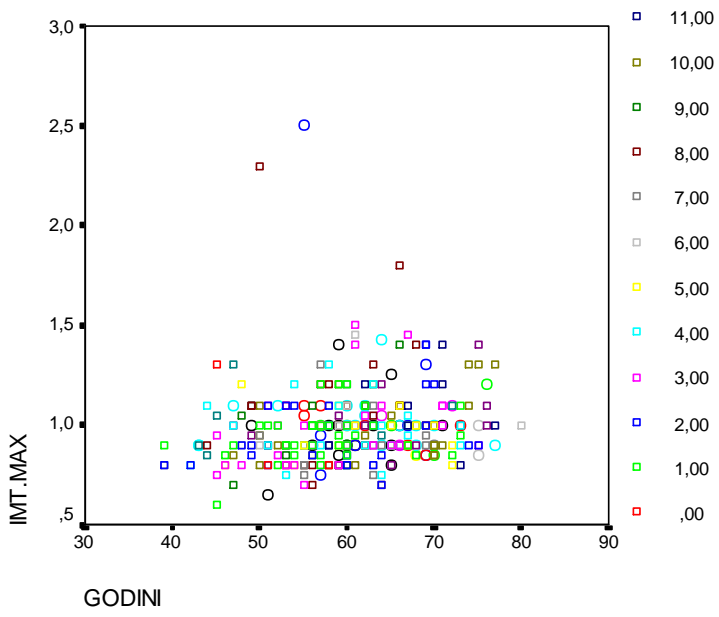

Figure 2 - Pearson correlation of maximal value of CIMT and age in type 2 diabetic pts

A systematic review by Brohall showed the presence of DM as equivalent to carotid ageing by 10 years [19b].

An age-dependent increase in carotid diameter can reflect age-associated changes in the carotid wall structure (alterations in the content and integrity of the structural matrix proteins, namely elastin and collagen). It is also worth noting, that in our healthy middle-aged population, an independent effect of age on carotid luminal diameter was observed much more in men than in women [123b].

Zunker and Mast described structural alteration in small penetrating brain arteries and arterioles, where medial smooth muscle first hypertrophied and was then replaced by extracellular matrix and plasma proteins. This is an aging phenomenon, but is exacerbated by diabetes mellitus and arterial hypertension [119120].

\section{Conclusion}

Carotid ultrasound measurement of IMT or detection of plaque or stenosis could provide prognostic information on asymptomatic type 2 diabetic patients, who at age $>60$ years presented a greater risk factor. Old people in the type 2 diabetic population presented a high prevalence of carotid artery disease and referred a high risk of ischaemic stroke. Although there is 
a likelihood of a higher prevalence of comorbidies in older patients, their treatment should be almost the same as in younger patients.

\section{REFERENCES}

1. Selby JV, Ray GT, Zhang D, et al. Excess costs of medical care for patients with diabetes in managed care population. Diabetes Care. 1997; 20: 1396-1402.

1b. Berry J, Keebler Me, McGuire DK. Diabetes Mellitus and Cardiovascular Disease: Pandora's Box has been opened. Herz. 2004; 29(5): 456-62.

2. Kissela BM, Khoury J, Kleindorfer D, et al. Epidemiology of Ischemic Stroke in Patients with Diabetes. The Greater Cincinnati/Northern Kentucky Stroke study. Diabetes care. 2005; 28: 355-359.

2b. Van Wijk I, Kappelle LJ, van Gijn J, Koudstaal PJ, Vermeulen G, Gorter JW, et al. Long-term survival and vascular event risk after transient ischemic attack or minor ischemic stroke: a cohort study. Lancet. 2005; 365(9477): 2098-104.

3. Sacco RL, Boden-Albala B, Abel G, Lin IF, Elkind M, Hause WA, et al. Race-ethnic disparities in in the impact of stroke risk factors in Northern Manhattan Stroke study . Stroke. 2001; 32: 1732-5.

3b. Mallick U, Dorobantu M, Iqbal B, Cheta D. An evidence based approach to the management of cardiovascular disease in Diabetes mellitus. In Cheta D. Vascular Involvment in Diabetes. Carger, Basel 2005.

4. Yamanouchi H, Shimada H, Kuramoto K. Subtypes and proportions of cerebrovascular disease in an autopsy series in a Japanese geriatric hospital. (Tokyo Metropolitan Geriatric Hospital series) Klin Wochenschr. 1990; 68: 1173-7.

5. Hillen T, Coshal C, Tilling K. on behalf of the South London Stroke register. Cause of stroke recurrence is multifactorial: patterns, risk factors, and outcome of stroke recurrence: The South London Stroke Register. Stroke. 2003; 34: 1457-63.

6. Kuusisto J, Mykkanene L, Pyorala K, Laakso M. Noninsulin dependent diabetes and its metabolic control are important predictors of stroke in elderly subjects. Stroke. 1994; 25: 1157-64.

7. Matz K, Jeresztes K, Tatschl C. Disorders if glucose metabolism in acute stroke patients: an unrecognized problem. Diabetes Care. 2006; 29: 792-7.

8. Karapanaytoides $\mathrm{T}$, Piechowsky-Jozwiak B, van Melle G. Stroke patterns, ethiology and prognosis in patients with diabetes mellitus. Neurology. 2004; 62: 1558-62.

9. Pinto A, Tuttolomondo A, Di Raimondo D, Di Sciacca R, Fernandez P, Di Gati M, et al. A case control study between diabetic and non-diabetic subjects with ischemic stroke. Int J Cardiol. 2008 Apr 25; 125(3):391-6.

10. Shah IM, Ghosh SK, Collier A. Stroke presentation in Type 2 diabetes and the metabolic syndrome. International Angiology. 2007; 26(01): 26-31.

11. Mohave MR, Hashenmazadeh M, Jamal MM. Diabetes mellitus is a strong independent risk factor for atrial fibrillation and flutter in addition to other cardiovascular disease. Int J Cardiol. 2005; 105: 315-8.
12. Fonarow GC, Srikanthan P. Diabetic cardiomyopathy. Endocrinol Metab Clin North Am. 2006; 35: 575-99.

13. Krahn AD, Manfreda J, Tate RB, Mathewson FA, Cuddy TE. The natural history of atrial fibrillation: incidence, risk factors, and prognosis in the Manitoba Follow-Up Study. Am J Med. 1995; 98: 476-84.

14. Benjamin EJ, Levy D, Vaziri SM, D’Agostino RB, Belanger AJ, Wolf PA. Independent risk factors for atrial fibrillation in a population-based cohort. The Framingham Heart Study. JAMA. 1994; 271: 840-44.

15. Lammie GA, Brannan F, Slattery J, Warlow C. Nonhypertensive cerebral small vessel disease: an autopsy study. Stroke. 1997; 28: 2222-9.

16. Arauz A, Murrillo L, Cantu C. Prospective study of single and multiple lacunar infarct using magnetic resonance imaging: risk factors, recurrence and outcome in 175 consecutive cases. Stroke. 2003; 34: 2453-8.

17. Rajala U, Laakso M, Painvansalo M. Blood pressure and atherosclerotic plaques in carotid, aortic and femoral arteries in elderly Finns with diabetes mellitus and impaired glucose tolerance. J Hum Hypertension. 2005; 19: 85-91.

18. Henefeld M, Koehler C, Henkel E, Fuecker K, Schaper F, Temelkova-Kurtschiev T. Postchallenge hyperglycemia relates more strongly than fasting hyperglycemia with carotid intima-media thickness: the RIAD study Diabetic Med. 2000; 17: 835-40.

19. Hancu N, Cerghizam A. Global approach to Cardiovascular Risk in Type 2 Diabetic Persons. In: Hancu N. Cardiovascular Risk in Type 2 Diabetes mellitus. Springer Verlag Berlin, Heidelberg, New York. 2003: 240-76.

19b. Brohall G, Behre CJ, Hulthe J, Wikstrand J, Fagerberg B. Prevalence of diabetes mellitus and impaired glucose tolerance in 64-year-old Swedish women: experiences of using repeated oral glucose tolerance tests. Diabetes Care. 2006; 29: 363-7.

20. 1 IRAS, 2 Kieschl S, Willeit J, for Bruneck Study Group. The natural course of atherosclerosis, part 1: incidence and progression. Arteriosc Thromb Vasc Biol. 1999; 34: 1484-90.

21. Selvin E, Coresh J, Golden SH. Glycemic control, Atherosclerosis, and Risk factors for cardiovascular Disease in Type 2 Diabetes. The Atherosclerosis Risk in Comunities Study. Diabetes Care. 2005; 28: 1963-75.

22. Göksan B, Erkol G, Bozluolcay M, Ince B. Diabetes as a determinant of high-grade carotid artery stenosis: Evaluation of 1,058 cases by Doppler sonography. J Stroke Cerebrovasc Dis. 2001; 10(6): 252-6.

23. Yang B, Li TD, Wang JS, Zhi G, Jin WS, Xu Y. Insulin resistance and carotid atherosclerosis in 221 patients with potentional hyperglycemia. Chin Med Sci. 2005; 20(2): 108-11.

24. Baldassarre D, de Jong A, Amato M, Werba PJ, Castelnuovo S, Frigerio B, et al. Carotid intima-media thickness and markers of inflammation endothelial damage and hemostasis. Ann Med. 2007; 1-24. 
25. Wang JG, Staessen JA, Li Y, Van Bortel LM, Nawrot T, Fagard R. Carotid intima-media thickness and antihypertensive treatment: a meta-analysis of randomized controlled trials. Ca antagonist and ACE reduce IMT. Stroke. 2006 Jul; 37(7): 1933-40.

26. Williams R, Aiery M. Epidemiology and pathogenesis of diabetic angiopathy. In: Tooke J. Diabetic angiopathy. Arnold 1999.

27. Ford ES, Giles WH, Dietz WH. Prevalence of the Metabolic Syndrome Among US Adults. JAMA 2002; 287: 356-9.

28. Pollex R, Al-Shalli KZ, House AA. Relationship of metabolic syndrome to carotid ultrasound traits. Cardiovascular Ultrasound. 2006; 4: 28-35.

29. Lu W, Resnick HE, Jablonski KA, et al. Non-HDL Cholesterol as a predictor of cardiovascular disease in type 2 diabetes: the Strong Heart Study. Diabetes Care. 2003; 26: 16-23.

30. Jiang R, Schulze M, Li Tricia, et al. Non-HDL Cholesterol and Apoplipoprotein B Predict Cardiovascular Disease Events Among Men With Type 2 Diabetes. Diabetes Care; 2004: 27: 1991-7.

31. De Vries R, Perton GF, Dallinga-Thie GM. Plasma cholesterol ester transfer is a determinant of intimamedia thickness in type 2 diabetic and nondiabetic subjects: role of CETP and triglycerides. Diabetes. 2005; 54(12): 3554-9.

32. Kawamoto R, Tomita H, Oka Y, Kodama A, Kamitami A. Metabolic syndrome amplifies the LDL-cholesterol associated increases in carotid atherosclerosis. Intern Med. 2005; 44(12): 1232-8.

33. Hulthe J, Bokemartk L, Wikstrand J, et al. The metabolic syndrome, LDL particle size, and atherosclerosis: The AIR study. Arterioscler Thromb Vasc Biol. 2000; 20: 2140-7.

34. Rajala U, Laakso M, Paivansalo M. Low insulin sensitivity measured by both quantitative insulin sensitive check index and homeostasis model assessment method as a risk factor of increased intima-media thickness of the carotid artery. J Clin Endocrinol Metab. 2002; 87: 5092-7.

35. Szernichow S, Bertrais S, Oppert JM, Galan P, Blacher J, Ducimetiere P, et al. Body composition and after repartition in relation to structure and function of a large arteries in middle-aged adults (the SU.VI.MAX study). Int J Obes. 2005; 29: 826-32.

36. Nomura M, Kasamai R, Ohashi M, Ymada Y, Abe. H. Significantly higher invcidence of carotid atheroscelrotiss found in japanese type 2 diabetic patients with early nephropathy. Diabetes Res Clin Pract. 2004; 66(1): 161-3.

37. Zhang L, Zhao F, Yang Y, Qi L, Zhang B, Wang F, et al. Association between carotid artery intimamedia thickness and early-stage CKD in a Chinese population. Am J Kidney Dis. 2007; 49(6): 786-92.

38. Tuimlehto J, Rastenyete D, Jousilahti P, Sarti C, Vartianinen E. Diabetes mellitus as a risk factor for death from stroke: prospective study of the middleaged Finnish population. Stroke. 1996; 27: 210-5.
39. Folsom AR, Rasmunssen ML, Chambles ME. Prospective associations of fasting insulin, body fat distribution, and diabetes with risk of ishaemic stroke. ARIC study. Diabetes Care. 1999; 22: 1077-83.

40. Megherbi SA, Mialn C, Minier D, et al. Association between diabetes and stroke subtype on survival and functional outcome 3 months after stroke. Data from from the European BIOMED Stroke project. Stroke. 2003; 344: 688-94.

41. Bonora E, Kiechl E, Oberhollenzer F. Imparied glucose tolerance, Type 2 diabetes mellitus and carotid atherosclerosis: prospective results from the Bruneck Study. Diabetologia. 2000; 43: 156-64.

42. Grag R, Chaudhuri A, Munscauer F. Hyperglycemia insulin and acute ischemic stroke: a mechanistic justification for a trial of insulin infusion therapy. Stroke. 20006; 37: 267-73.

43. Selvin E, Coresh J, Golden SH. Glycemic control, Atherosclerosis, and Risk factors for cardiovascular Disease in Type 2 Diabetes. The Atherosclerosis Risk in Communities.

44. Jorgensen H, Nkayama H, Raaschou HO, Olsen TS, Stroke in patients with diabetes. The Copenhagen Stroke Study. Stroke. 1994; 25: 1977-84.

45. Lithner F, Asplund K, Eriksson S, Haag E, Strand T, Wester PO. Clinical characteristics on diabetic stroke patients. Diab Metab. 1988; 14: 15-19.

46. Toni D, Sacchetii Ml, Argentino C, Gentile M, Cavalleti $\mathrm{C}$, Frontoni M, et al. Does hyperglycemia play a role on the outcome of ishemic stroke patients? J Neurol. 1992; 239: 382-6.

47. Kiers L, Davis SM, Larkins R, Hopper J, Tress B, Rossiter SC, et al. Stroke topography and outcome in relation to hyperglicaemia and diabetes. J Neurol Neurosurg Psychiatry. 1992; 55: 263-70.

48. Pulsinelli WA, Levy DE, Sigsvee B, Scherer P, Plum F. Increased damage after ischemic stroke in patients with hyperglicaemia with or without established diabetes mellitus. Am J Med. 1983; 74: 540-4.

49. Peila R, Rodriquez BL, Launer LI. Type 2 diabetes, APOE Gene, and the risk for Dementia and related pathologies. Honolulu Asia-Aging study. Diabetes. 2002; 52: 1256-62.

50. Korf ESC, White LR, Scheltens P, Launer LJ. Brain Aging in Very old men with type 2 diabetes. Diabetes Care. 2006; 29(10): 2268-74.

51. Albers GW, Dalen JE, Laupacis A. Antithrombotic therapy in atrial fibrillation. Chest. 2001; 119; $1945-$ 2065.

52. Fuster V, Ryden LE, Asinger RW, Cannon DS, Crijns HJ, Frye RL, et al. ACC/AHA/ESC guidelines for the management of patients with atrial fibrillation. Eur Heart J. 2006; 27: 1979-2030.

53. Gage BF, Waterman AD, Shannon W. Validation of clinical classification schemes for predicting stroke: results from the National Registry of Atrial Fibrillation. JAMA. 2001; 285: 2864-70.

54. Wang TJ, Massaro JM, Levy D. A risk score for predicting stroke or death in individuals with new-onset atrial fibrillation in the community: the Framingham Heart Study. JAMA. 2003; 290: 1049-1056. 
55. Adler A, Stratton I, Neil H. Association of systolic blood pressure with macrovascular and microvascular complications of type 2 diabetes (UKPDS 36): prospective observational study. BMJ. 2000; 321: 17: 412-9.

56. Chalmers J, Joshi R, Patel A. Advances in reducing the burden of vascular disease in type 2 diabetes. Clin Exp Pharmacol Physiol. 2008 Apr; 35(4): 434-7.

57. Tuomilehto J, Rastenyte D, Birkenhager WH. Effects of calcium-channel blockade on older patients with diabetes and systolic hypertension. (Syst-Eur). N Engl J Med. 1999; 340: 677-84.

58. Soucek M. Diabetes Mellitus cerebrovascular disease. Vnitr Lek. 2003 Dec; 49(12): 916-20

59. The Task Force on Diabetes and Cardiovascular Disease of the European Society of Cardiology and of the European Association of the Study of Diabetes. doi.10.1093/eurheartj/ehl261.

60. Khan NA, Hemmelgarn B, Herman RJ, Rabkin SW, McAlister FA, Bell CM, et al. The 2008 Canadian Hypertension Education Program recommendations for the management of hypertension: part 2 - therapy. Can J Cardiol. 2008; 24(6): 465-75.

61. Kawamura T. Cerebrovascular disease and diabetic patients with hypertension. Nippon Rinsho. 2003 Jul; 61(7): 1175-80.

62. Hirsh J, Bhatt DL. Comparative benefits of clopidogrel and aspirin in high-risk patient populations: lessons from the CAPRIE and CURE studies. Arch Intern Med. 2004; 164: 2106-10.

63. Bosevski M, Georgievska Lj, Borozanov V. Dual antithrombotic therapy and hypercoagulability in diabetic patients. Am Heart J. 2008; 155(6): e47.

64. Serebruany VL, Malinin AI, Pokov A, Barsness G, Hanley DF. Effects of clopidogrel and aspirin in combination versus aspirin alone on platelet activation and major receptor expression in diabetic patients: the PLavix Use for Treatment Of Diabetes (PLUTO-Diabetes) trial. Am Heart J. 2008 Jan; 155(1): 93.e1-7.

65. Williams LS, Rotich J, Qi R, Fineberg N, Espay N, Bruno A, et al. Effects of admission hyperglycemia on mortality and costs in acute ischemic stroke. Neurology 200259; 67-71 x 68. UKPDS 33. Lancet. 1998; 352: 837-53.

66. Diabetes Prevention Research Programme. reduction in the incidence of type 2 diabetes with lifestyle modification and or metformin. N Engl J Med. 2002; 346: 394-46.

67. Heart protection study Collaboration Group. MRC/BHF Heart Protection Study of cholesterollowering in 5963 people with diabetes: a randomized placebo-controlled trial. Lancet. 2003; 361: 2005-16.

67b. Chambers BR, Roberts NG. Asymptomatic carotid artery stenosis. Current Treatment in Cardiovascular Medicine. 2007; 9(2): 81-89.

68. Eton D. Surgery and Medical Management of Cerebrovascular Disease in: Eton D. Vascular Disease: A Multi-Specialty approach to Diagnosis and Management, Landes Bioscience, Austin 1999.
69. Reina-Gutierrez T, Serrano-Hernanado FJ, SanchezHervas L. Recurrent carotid artery stenosis following up endarterectomy: natural history and risk factors. Euro J Vasc Endovasc Surg. 2005; 29(4): 334-41.

70. Tropeano AI, Boutouyrie P, Katsahian S. Glucose level is a major determinant of carotid intima-media thickness in patients with hypertension and hyperglycemia. J Hypertension. 2004; 22(11): 2153-60.

71. Levy EI, Mocco J, Samuelson RM, Ecker RD, Jahromi BS, Hopkins N. Optimal treatment of carotid artery disease. JACC 2008; 51(10): 979-985.

72. Chambers BR, Donnan GA. Carotid endarterectomy for asymptomatic carotid stenosis. Cochrane Database Sys Rev. 2005; 2: CD001923.

73. Coward Lj, Featherstone RL, Brown MM. Safety and efficacy of endovascular treatment of carotid treatment of carotid artery stenosis compared with carotid endarterectomy: a Cochrane systematic review of the randomized evidence. Stroke. 2005; 36: 905-11.

74. Hancu N, Cerghizan, Cornelia B. Practical approach to the multifactorial risk in type 2 diabetes. In Cheta D. Multivacsular involvement in Diabetes. Karger, Basel 2005.

75. Stevens RJ, Kothari V, Adler AI, Stratton IM, Holman RR, on behalf of the UKPDS Group. The UKPDS risk engine: a model for the risk the coronary heart disease in type 2 diabetes (UKPDS 56). Clinical Science. 2001; 101: 671-9.

76. Kothari V, Stevens RJ, Adler AJ, Stratton IM, Manley SE, Neil A, Holman RR, for the UKPDS Group (UKPDS 60) Risk for stroke in the 2 diabetes estimated by UKPDS risk engine. Stroke. 2002; 33: 776-1781.

77. Song SH, Brown PM. Coronary heart disease risk assessment in diabetes mellitus: comparison of UKPDS risk engine with Framingham risk assessment function and its clinical implications. Diabetic Medicine. 2003; 21: 238-245.

79. Haffner SM, Lehot S, Ronnemaa T, et al. Mortality from coronary heart disease in subjects with type 2 diabetes and in nondiabetic subjects with and without prior myocardial infarction. N Engl J Med. 1998; 339: 229-34.

80. Doney A, Lee S, Leese G, Morris A, Palmer C. Increased Cardiovascular Morbidity and Mortality in Type 2 Diabetes Is Associated With Glutathione S Transferase Theta-Null Genotype (A Go-DARTS Study). Circulation. 2005; 111: 677-88.

81. Morrish NJ, Steven LK, Head J, et al. A prospective study of mortality among middle-aged diabetic patients (the London cohort of the WHO multinational study of vascular disease in diabetics) Diabetologia. 1990, 33: 542-8.

82. Saydah SH, Fradkin J, Cowie CC. Poor control of risk factors for vascular disease among adults with previously diagnosed diabetes. JAMA 2004; 291(3): 335-42.

83. Orchard TJ, Strandness DE Jr. Assessment of peripheral vascular disease in diabetes. Report and recom- 
mendations of an international workshop sponsored by the American Heart Association and the American Diabetes Association Diabetes Care. 1993 Aug; 16(8): 1199-209.

84. De Angelis M, Scrucca L, Leandri M, et al. Prevalence of carotid stenosis in type 2 diabetic patients asymptomatic for cerebrovascular disease. Diabetes Nutr Metab. 2003 Feb; 16(1): 48-55.

84b. Lacroix P, Aboyans V, Criqui MH, Bertin F, Bouhamed T, Archambeaud F, Laskar M. Type 2 diabetes and carotid stenosis: a proposal for a screening strategy in asymptomatic patients. Vascular Medicine. 2006; 11: 93-99.

85. Lorenz MW, Markus HS, Bots MI, et al. prediction of Clinical Cardiovascular Events with Carotid Intima-Media Thickness. Circulation. 2007; 115: 459467.

86. Duval M, Altman JJ. When should ultrasonography be used to detect asymptomatic carotid atheroma in diabetic patients? Diabetes Metab. 2006 Dec; 32(6): 638-42.

86b. Bosevski M, Borozanov V, Vavlukis M, Pemovska $\mathrm{G}$, Georgievska-Ismail Lj. Carotid ultrasound, blood lipids and waist determination can predict a future coronary revascularisation in the type 2 diabetic cohort. Prilozi. 2007; 28(2): 127-36.

87. Bernard S, Serusclar A, Targe F, et al. Incremental predictive value of carotid ultrasonography in the assessment of coronary risk in a cohort of asymptomatic type 2 diabetic subjects. Diabetes Care. 2005; 28(5): 1158-9.

88. Parikh A, Daneman D. Is Carotid Ultrasound a Useful Tool in Assessing Cardiovascular Disease in Individuals with Diabetes? Diabetes Technology \& Therapeutics. 2004; 6(1): 65-9.

89. Yokoyama H, Katakami N, Yamasaki Y. Recent advances of intervention to inhibit progression of carotid intima-media thickness in patients with type 2 diabetes mellitus. Stroke. 2006; 37(9): 2420-7.

90. Bots ML, Evans GW, Riley WA, Grobbe DE. Carotid intima-media thickness Measurements in Intervention studies. Stroke. 2003; 34: 2985-94.

91. Spence JD. Ultrasound measurements of carotid plaques as a surrogate outcome for coronary artery disease. Am J Cardiol. 2002; 89 (suppl): 10B-16B.

92. Giral P, Brucket E, Daiorrou F. Usefulness in predictting coronary artery disease by ultrasonic evaluation of the carotid arteries in asymptomatic hypercholesterolemic patients with positive exercise stress test. Am J Cardiol. 1999; 84: 14-17.

93. Lee EJ, Kim HJ, Bae JM, et al. Relevance of common carotid intima-media thickness and carotid plaque as risk factors for ischemic stroke in patients with type 2 diabetes mellitus. Am J Neuroradiol. 2007; 28(5): 916-9.

94. Giral P, Brucket E, Daiorrou F. Usefulness in predicting coronary artery disease by ultrasonic evaluation of the carotid arteries in asymptomatic hypercholesterolemic patients with positive exercise stress test. Am J Cardiol. 1999; 84: 14-17.
95. Lorenz M, Markus H, Bots M, Rosval M, Sitzer M. Prediction of Clinical Cardiovascular Events with Carotid Intima-media thickness: A systematic review and Meta-analysis. Circulation. 2007; 115: 459-67.

95b. De Angelis M, Strucca L, Leandri M. Prevalence of carotis stenosis in type 2 diabetic pts asymptomatic for cerebrovascular disease. Diabetes Nutr Metab. 2003; 16: 48-55.

96. Bosevski M, Influence of metabolic risk factors for presence of carotid artery disease in patients with type 2 diabetes and coronary artery disease. Diab Vasc Dis Res. 2007; 4(1): 49-52.

97. Lacroix P, Aboyans V, Criqui MH, Bertin F, Bouhamed T, Archambeaud F, Laskar M. Type-2 diabetes and carotid stenosis: a proposal for a screening strategy in asymptomatic patients.Vasc Med. 2006; 11(2): 93-9.

98. Parikh A, Daneman D. Is Carotid Ultrasound a Useful Tool in Assessing Cardiovascular Disease in Individuals with Diabetes? Diabetes Technology \& Therapeutics. 2004; 6(1): 65-9.

99. Bosevski M, Peovska I, Georgievska-Ismail L. Noninvasive imaging of diabetic vascular disease. Review in Cardiovascular Medicine 2008; Fall (in press)

100. Ragi P, Bellasi A, Ratti C. Ischemia Imaging and Plaque Imaging in Diabetes. Diabetes Care. 28: 2787-2794, 2005.

101. Charvat J, Michalova K, Chlumsky J, Horácková M, Valenta Z, Zdárska D. The significance of carotid artery plaques in the detection of coronary artery disease in asymptomatic type 2 diabetic patients. J Int Med Res. 2006; 34(1): 13-20.

102. Mudríková T, Szabová E, Tkác I. Carotid intimamedia thickness in relation to macrovascular disease in patients with type 2 diabetes mellitus. Wien Klin Wochenschr. 2000; 112(20): 887-91.

103. Bernard S, Sérusclat A, Targe F, Charrière S, Roth $\mathrm{O}$, Beaune $\mathrm{J}$, et al. Incremental predictive value of carotid ultrasonography in the assessment of coronary risk in a cohort of asymptomatic type 2 diabetic subjects. Diabetes Care. 2005; 28(5): 1158-62.

104. Kitagawa K, Hougaku H, Yamagami H, Hashimoto H, Itoh T, Shimizu Y, et al., for OSACA2 Study Group. Carotid intima-media thickness and risk of cardiovascular events in high-risk patients. Results of the Osaka Follow-Up Study for Carotid Atherosclerosis 2 (OSACA2 Study). Cerebrovasc Dis. 2007; 24(1): 35-42.

105. Brohall G, Oden A, Fagerberg B. Carotid artery intima-media thickness in patients with type 2 diabetes mellitus and impaired glucose tolerance: a systemic review. Diabetic Medicine. 2005; 23: 609-616.

106. Hodis HM, Mack WJ, LaBree L, Seizer RH, Liu $\mathrm{CH}$, Azen SR. The role of carotid intima-media thickness in predicting clinical coronary events. Ann Intern Med. 1998; 128: 262-9.

107. Yamasaki Y, Kodama M, Nishizawa H, Sakamoto K, Matsuhisa M, Kajimoto Y, et al. Carotid IntimaMedia thickness in Japanese Type 2 Diabetic Sub- 
jects. Predictors of progression and relationship with incident coronary heart disease. Diabetes Care. 2000; 23(9): 1310-5.

108. Salonen R, Nyyssonen K, Porkkala E. Kuopio Atherocslerosis Prevention Study (KAPS). A population-based primary preventive trial of the effect of LDL lowering in atherosclerotic progression in carotid and femoral arteries. Circulation. 1995; 92: 175864.

109. Chambless LE, Folsom AR, Davis V, Sharett R, Heiss C, Sortlie P, et al. Risk factors for progression of common carotid atherosclerosis: the Atherosclerosis Risk in Communities Study, 1979-1998. Am J Epidemiol. 2002; 155: 38-47.

110. Zuriek M, Touboul PJ, Bonithon-Kopp C, Courbon D, Berr C, Leroux C, Ducimetiere P. Cross sectional and 4-year longitudinal associations between brachial pulse pressure and common carotid intimae-media thickness in a general population. The EVA study. Stroke. 2002; 33: 550-5.

111. Mackinnon AD, Jerrard Dune P, Sitzer M, Biehler A, von Kegler S, Markus HS. Rates and determinants of site-specific progression of carotid intima-media thickness: the carotid atherosclerosis progression study (CAPS). Stroke. 2004; 35: 2150-4.

112. Go AS, Hylek EM, Phillips KA, Chang Y, Henaulst LE, Selby JV, Singer DE. Prevalence of diagnosed atrial fibrillation in adults: national implications for rhythm management and stroke prevention: the Anticoagulation for rhythm management and stroke prevention: the Anticoagulation and Risk Factors in Atrial Fibrillation (ATRIA) Study. JAMA 2001; 285: 2370-75.

113. AF Investigators. Risk factors for stroke and efficacy of antithrombotic therapy in atrial fibrillation: analysis of pooled data from the randomized controlled trials. Arch Intern Med. 1994; 154: 1449-57.

114. Korf ES, White LR, Scheltens P, Launer LJ. Brain aging in very old men with type 2 diabetes: the Honolulu-Asia Aging Study. Diabetes. 2006; 29(10): 2268-74.

115. Girdia Cb, Avogaro A, Maggini M, Lombardo F, Mannuci E, Turco S, et al. Incidence and risk factors for stroke in type 2 diabetes. Stroke. 2007; 38: 1154 60.

116. Schram MT, Kostense PJ, Van Dijk RA, Dekker JM, Nijpels G, Bouter LM, et al. Diabetes, pulse pressure and cardiovascular mortality: the Hoorn Study. J Hypertens. 2002; 20(9): 1743-51.

117. Hendbald B, Nilsson P, Janzon L, Berglund G. Relation between insulin resistance and carotid intiamedia thickness and stenosis in non-diabetic subjects. Results from a cross sectional study in Malmo. Sweden. Diabet Med. 2000; 17: 299-307.

118. Brohall G, Oden A, Fagberg B. Carotid artery intima-media thickness in patients with type 2 diabetes mellitus and impaired glucose tolerance: a systematic review. Diabetic Medicine. 2005; 23: 609-16. 118b. Najjar, SS, Scuteri A, Lakatta EG . Arterial aging. Is it an immutable ardiovascular risk factor? Hypertension. 2005; 46: 454-462.

119. Zunker P, Sxhick A, Buschmann HC, Georgiadis D, Nabavi D, Edelmann M, et al. Hyperinsulinism and cerebral microangiopathy. Stroke. 1996; 27: 219-23.

120. Mast H, Thompson JL, Lee Sh, Mohr JR, Sacco RL. Hypertension and diabetes mellitus as determinants for multiple lacunar infarcts. Stroke. 1995; 26: 30-3.

\section{Резиме}

\section{риј н ошевски}

Универзитетска клиника за кардиологија, Медицински факултет, „Св. Кирил и Методиј“, Скопје, Р. Македонија

Постојат два клучни аспекта за заемното дејство на каротидната артериска болест (КАРБ) и дијабетесот (ДМ): ДМ е препознат како еден од најзначајните фактори за присуство и прогресија на асимптоматската и симтоматската КАРБ и вредноста на дебелината на интима медијата е дефинирана како корисна алатка за ризик- стратификацијата на оваа популација.

Хипергликемијата, времетраењето на дијабетесот, артериската хипертензија, холестеролот и инфламаторните маркери се предодредени за независни фактори за каротидната атеросклероза кај пациентите со ДМ, додека, пак, возраста според сопствените резултати. Овој труд се фокусира на поединостите на ризик-факторите на пациентите со ДМ (особено тип 2 дијабетес), како и водичите на медицината базирана на докази за лекување и намалување на ризикот на овие пациенти од мозочен удар и/или КАРБ.

Актуелно, каротидниот ултразвук се препорачува кај пациентите со ДМ и цереброваскуларна симптоматологија. Како што преваленцијата на ДМ се зголемува постојано, има обид за обновување на критериумите за скрининг на КАРБ кој популацијата со ДМ. Таа би можела да се препорача кај пациентите со ДМ и најмалку уште еден фактор на ризик или, пак, оние на возраст над 60 години.

лучни зборови: каротидна артериска болест, дијабетс, мозочен удар, каротиден ултразвук, стареење, прогноза. 